\title{
DETEKSI GERAK OBJEK BERBASIS PENGOLAHAN CITRA MENGGUNAKAN METODE BINARY-IMAGE COMPARISON
}

\section{OBJECT MOTION DETECTION BASED ON IMAGE PROCESSING USING BINAR Y-IMAGE COMPARISON METHOD}

\author{
Matalangi $^{1}$, Abdul Jalil ${ }^{2}$ \\ ${ }^{1}$ Jurusan Sistem Komputer, STMIK Handayani Makassar \\ ${ }^{2}$ Jurusan Sistem Komputer, STMIK Handayani Makassar \\ 1'
}

\begin{abstract}
Abstrak
Tujuan penelitian ini adalah membangun sistem deteksi gerak objek berbasis teknik pengolahan citra menggunakan metode Binary-Image Comparison (BIC). Fungsi metode BIC pada penelitian ini adalah sebagai pengambil keputusan pada saat sistem mengirim data message sebagai hasil dari deteksi gerak objek. Adapun gerak objek yang dideteksi pada penelitian ini adalah objek dengan warna merah, kuning, hijau, dan biru. Pada penelitian ini, proses segmentasi citra biner diproses menggunakan perangkat lunak Library OpenCV yang dieksekusi didalam node Robot Operating System 2 (ROS2). Terdapat beberapa node ROS2 yang digunakan untuk membangun sistem deteksi gerak objek pada penelitian ini, yaitu node untuk membaca input kamera RGB, node untuk mendeteksi gerak objek warna merah, node untuk mendeteksi gerak objek warna kuning, node untuk mendeteksi gerak objek warna hijau, node untuk mendeteksi gerak objek berwarna biru, dan node untuk menerima hasil proses deteksi warna. Setiap node pada sistem tersebut dapat saling terhubung melalui topic untuk dapat saling bertukar data message menggunakan protokol Data Distribution Service (DDS) yang ada pada ROS2. Hasil dari penelitian ini adalah sistem dapat mendeteksi gerak objek warna merah, kuning, hijau, dan biru kemudian mengirimnya sebagai data message berdasarkan hasil keputusan dari metode BIC.
\end{abstract}

\section{Kata kunci : Pengolahan citra, Binary-image comparison, ROS2}

\begin{abstract}
The purpose of this study is to build the object motion detection system based on the image processing technique used a Binary-Image Comparison (BIC) method. The function of the BIC method in this study is as a decision-maker to make the system be able to send the message data as a result of object motion detection. The object motion has detected in this study is the object with a colour of red, yellow, green and blue. In this study, the image processing segmentation has been processed using OpenCV library software and was executed in the Robot Operating System 2 (ROS2) nodes. Some of the ROS2 nodes have been used to build the object motion detection on this study, that is a node to read the RGB camera input, a node to detect the red object motion, a node to detect the yellow object motion, a node to detect the green object motion, a node to detect the blue object motion, and a node to receive the result of motion detection object. Each node in this systems will be connected to each other through a topic to make them are able to exchange the image message data using the Data Distribution Service (DDS) protocol on the ROS2. The result from this study is the systems can be detected the object motion are red, yellow, green, and blue then sent it as a message data based on the resulting process from the $B C I$ method.
\end{abstract}

Keywords: Image processing, Binary-image comparison, ROS2 


\section{PENDAHULUAN}

Kamera merupakan sebuah alat input yang dapat digunakan untuk mendeteksi objek berupa gambar atau video. Pemanfaatan kamera sebagai alat input telah dikembangkan oleh banyak peneliti dan telah dimanfaatkan oleh masyarakat seperti pemanfaatan kamera untuk sistem keamanan rumah[1], sebagai alat pemantau suatu unit usaha di PTN berbasis IP Camera[2], sebagai alat monitoring kesehatan tanaman kelapa sawit[3], sebagai alat untuk mendeteksi api[4,5], dan sebagai alat untuk mendeteksi nominal uang pada mesin penukaran uang kertas rupiah[6]. Pada penelitian ini, peneliti akan memanfaatkan kamera sebagai alat untuk mendeteksi gerak objek berdasarkan warna objek.

Penelitian yang membahas tentang sistem deteksi gerak objek telah dikembangkan oleh beberapa peneliti, diantaranya adalah pemanfaatan kamera untuk mendeteksi dan melacak objek bergerak pada UAV, pada penelitian tersebut peneliti menggunakan metode segmentation using edge based dilation (SUED) untuk mendeteksi gerak objek[7]. Peneliti pada [8] telah memanfaatkan kamera untuk mendeteksi gerak objek berwarna merah secara realtime menggunakan metode color filtering, pada penelitian tersebut peneliti menggunakan teknik objek tracking untuk mendeteksi objek bergerak berwarna merah. Selain itu, peneliti pada [9] telah membuat aplikasi pendeteksi objek bergerak pada image sequence menggunakan metode background substraction, peneliti tersebut telah menggunakan aplikasi MATLAB untuk mendeteksi objek bergerak. Sistem deteksi gerakan pada kamera CCTV telah diaplikasikan oleh peneliti [10], pada penelitian tersebut peneliti menggunakan algoritma frame difference dan frame substraction untuk mendeteksi gerak dan memeriksa objekobjek pada citra. Selanjutnya pada penelitian [11], peneliti mendesain dan mengimplementasikan visual object tracking menggunakan pan dan tilt vision system, dengan menggunakan metode tersebut peneliti dapat meningkatkan kinerja kamera dalam pemantauan area kerja yang luas.

Pada penelitian ini, peneliti akan membangun sebuah sistem deteksi gerak objek berdasarkan warnanya yaitu merah, kuning, hijau, dan biru kemudian menggunakan metode Binary-Image Comparison (BIC) sebagai pengambil keputusan pada saat mengirim data message ROS. Proses segmentasi citra pada penelitian ini akan dieksekusi menggunakan OpenCV yang beroperasi didalam node Robot Operating System 2 (ROS2). Terdapat beberapa node ROS2 yang akan digunakan pada penelitian ini untuk dapat mengaplikasikan sistem deteksi gerak yang dibangun, yaitu node untuk membaca input kamera RGB, node untuk mendeteksi gerak objek warna merah, node untuk mendeteksi gerak objek warna kuning, node untuk mendeteksi gerak objek warna hijau, dan node untuk mendeteksi gerak objek warna biru. Setiap node tersebut akas saling terhubung dan berkomunikasi melalui topic untuk mengirim data message dari kamera ke setiap node deteksi objek dan dari node deteksi objek ke node proses hasil.

\section{MATERIAL DAN METODOLOGI}

\subsection{Teknik Pengolahan Citra}

Cirta merupakan sebuah gambar atau foto tampilan dua dimensi yang menampilkan visualisasi sebuah objek, citra tersebut dapat ditampilkan dalam bentuk cetak ataupun dalam bentuk digital[12]. Dalam teknik pengolahan citra, terdapat citra gambar yang akan diproses sebagai input kemudian akan menghasilkan citra sebagai output[13], teknik ini dapat dilakukan dengan menggunakan komputer sebagai alat komputasi untuk melakukan proses pengolahan citra. Dalam sebuah citra digital, terdapat sebuah matriks dua dimensi $\mathrm{f}(\mathrm{x}, \mathrm{y})$ yang terdiri dari kolom $\mathrm{M}$ dan baris $\mathrm{N}$, dimana perpotongan antara kolom dan baris disebut sebagai pixel atau elemen terkecil dari sebuah citra.

Terdapat tiga jenis citra digital yang secara umum digunakan dalam teknik pengolahan citra, yaitu citra gambar yang memiliki warna RGB (Red, Green, Blue). Pada citra gambar berwarna, 
Jurnal Elektro Luceat [July] [2020]

masing-masing pixel memiliki warna tertentu yaitu warna merah (Red), hijau (Green), dan biru (Blue), masing-masing dari warna tersebut akan memili nilai range dari 0 hingga 255. Kedua adalah citra gambar yang memiliki warna hitam dan putih (greyscale), pada citra gambar tersebut setiap pixelnya akan memiliki warna gradasi mulai dari putih hingga hitam dengan rentang nilai pixel yaitu 8 bit atau 1 byte. Selanjutnya yang ketiga adalah citra gambar hitam putih dalam bentuk binary image, pada citra tersebut setiap pixelnya hanya terdiri dari warna hitam atau putih atau memiliki nilai 1 bit per pixel yaitu 0 dan 1[14]. Pada penelitian ini, peneliti akan menggunakan teknik pengolahan citra digital dalam bentuk binary image yang akan digunakan untuk mendeteksi gerak objek berdasarkan warnanya dan diproses menggunakan teknik thresholding image. Thresholding adalah sebuah metode teknik pengolahan citra yang digunakan untuk memisahkan objek dengan background[15].

\subsection{Binary-Image Comparison}

Binary-Image Comparison (BIC) adalah metode yang digunakan untuk membandingkan dua buah citra atau lebih dalam bentuk binary-image. Pemanfaatan binary-image comparison pada sistem pengolahan citra telah di aplikasikan oleh peneliti [16], pada penelitian tersebut peneliti mengembangkan metode binary-image comparison dengan local-dissimilarity quantification menggunakan teknik windowed Hausdorff distance. Selanjutnya pada penelitian [17], peneliti mengembangkan teknik comparison of binary images dengan menggunakan metode perbandingan garis edge citra dengan memodifikasi jarak Hausdroff yang disebut censored Hausdorff distance. Selain itu, peneliti [18] telah mengembangkan fast size-invariant binary image matching menggunakan teknik pendeteksian perbedaan dari mapping pixel.

Pada penelitian ini, peneliti menggunakan metode BIC sebagai pengambil keputusan untuk mengirim data message pada saat sistem mendeteksi gerak objek. Teknik deteksi citra biner pada penelitian ini diproses didalam node ROS2 dengan memanfaatkan library OpenCV dalam melakukan thresholding gambar dan mengolah citra biner. Terdapat dua citra biner yang akan dikomparasi dalam setiap proses node ROS2, yaitu citra biner yang digunakan untuk menentukan nilai objek warna dan citra biner master yang akan menjadi pembanding dari nilai citra biner warna. Berikut adalah algoritma yang digunakan untuk mendeteksi gerak objek berdasarkan warna menggunakan metode BIC.

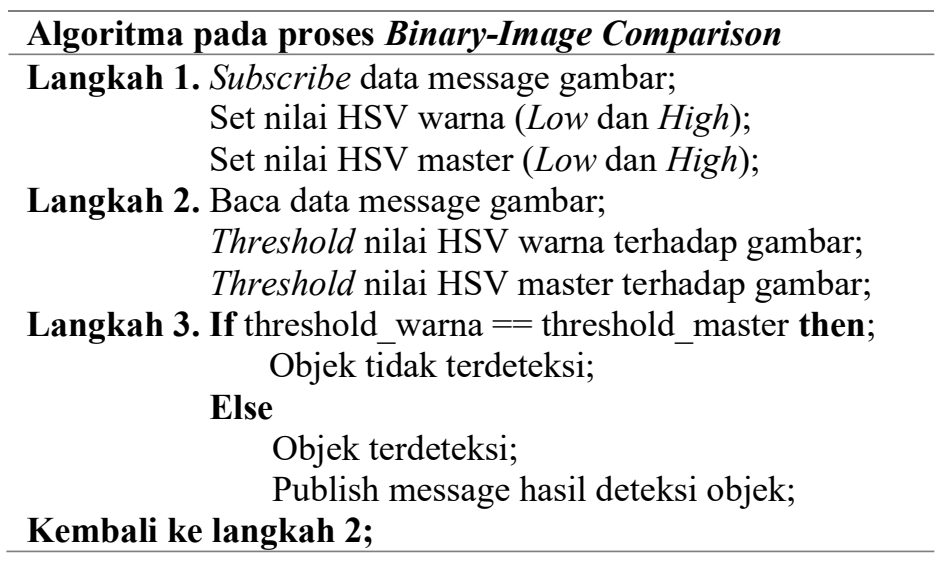

Pada algoritma yang telah dibangun, terdapat tiga langkah yang dilakukan untuk dapat mendeteksi gerak objek berdasarkan warna menggunakan metode binary-image comparison. Langkah pertama adalah sistem akan menerima atau men-subscribe data message gambar yang dikirim dari node camera, setelah itu menetapkan nilai HSV Low dan High untuk menentukan nilai 
Jurnal Elektro Luceat [July] [2020]

citra warna objek seperti merah, kuning, hijau, atau biru. Selanjutnya, menetapkan nilai HSV master Low dan High yang akan digunakan sebagai pembanding nilai citra biner dengan citra biner objek. Langkah kedua, sistem akan membaca data message gambar yang telah di subscribe, kemudian melakukan thresholding image berdasarkan citra gambar yang diterima dengan nilai HSV warna dan master. Selanjutnya langkah ketiga, pada langkah ini metode Binary-Image Comparison diaplikasikan, pada langkah tersebut sistem akan membandingkan hasil nilai thresholding antara citra biner warna dengan citra biner master. Jika nilai hasil threshold citra warna sama dengan threshold master, maka sistem akan memutuskan bahwa objek tidak tersedeteksi. Kemudian jika nilai hasil threshold citra warna tidak sama dengan threshold master, maka sistem telah berhasil mendeteksi objek dan mengirim data message ke node proses hasil. Berikut adalah flowchart dari algoritma yang diterapkan pada proses metode BIC.

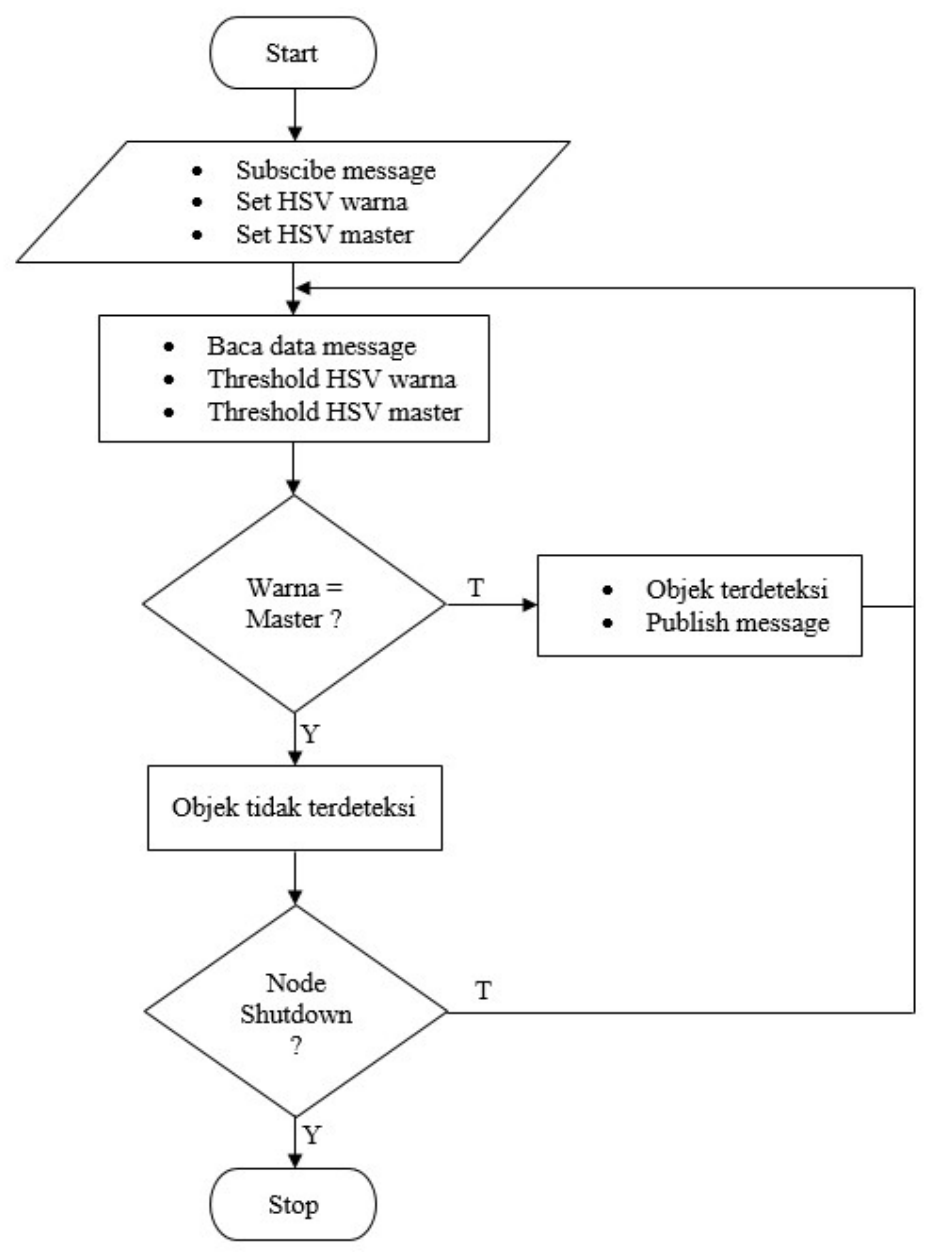

Gambar 1. Flowchart proses pada metode binary-image comparison

\subsection{Robot Operating System}

Robot Operating System (ROS) merupakan perangkat lunak kontrol yang dapat digunakan untuk mengontrol perangkat keras robot. Pemanfaatan ROS sebagai perangkat lunak robot dapat dikembangkan untuk sistem pembelajaran robot menggunakan ROS dan Gazebo[19] serta untuk mengontrol perangkat keras menggunakan Raspberry Pi[20]. Pada saat ini komunitas ROS telah mengembangkan dua jenis ROS yaitu ROS1 dan ROS2. Perbedaan mendasar antara ROS1 dan ROS2 
adalah pada protokol yang digunakan untuk mengkomunikasikan data message antara node melalui topic. Adapun protokol yang digunakan pada ROS1 adalah TCPROS/UDPROS[21] sedangkan pada ROS2 menggunakan Data Distribution Service (DDS)[21][22]. Selain itu, perbedaan lainnya adalah pada saat menjalankan proses ROS, pada ROS1 untuk menjalankan proses ROS membutuhkan rosmaster sedangkan pada ROS2 dapat langsung dijalankan tanpa rosmaster. ROS2 juga telah mendukung sistem komunikasi data secara realtime, sedangkan ROS1 belum mendukung sistem tersebut.

Pada penelitian ini, peneliti akan menggunakan ROS2 untuk memproses seluruh sistem yang ada pada sistem deteksi gerak objek berdasarkan warna objek, seluruh proses tersebut akan dijalankan didalam node ROS. Pada sistem ROS terdapat node, topic dan message. Node adalah proses komputasi yang berjalan pada sistem ROS, terdapat dua jenis node yaitu node publisher dan node subscriber. Node publisher adalah node yang digunakan untuk mengirim data message sedangkan node subscriber adalah node yang digunakan untuk menerima data message melalui topic. Topic adalah nama jalur yang digunakan untuk mengirim data message antar node, sedangkan message adalah data yang diproses didalam node dan dikirim melalui topic. Terdapat beberapa jenis tipe data message ROS diantaranya adalah Image, String, Float, Integer, Boolean, dan lain-lain.

\section{PEMBAHASAN}

Sistem deteksi gerak objek berbasis pengolahan citra telah di aplikasikan pada penelitian ini. Peneliti telah menggunakan ROS2 sebagai perangkat lunak kontrol untuk dapat mendeteksi gerak objek berdasarkan citra. Pada ROS2 terdapat node yang berfungsi sebagai pusat komputasi untuk mengolah data message kemudian mengirimnya melalui topic. Setiap node yang dibangun pada sistem ROS mempunyai nama unik yang berbeda-beda, kemudian dapat saling berkomunikasi menggunakan topic. Syarat utama agar node ROS dapat saling berkomunikasi adalah nama topic antara node harus sama, jika tidak maka node tidak dapat saling berkomunikasi. Berikut adalah tabel nama node yang digunakan pada penelitian ini beserta dengan fungsinya.

Tabel 1. Nama node dan fungsinya

\begin{tabular}{|c|l|}
\hline Node & \multicolumn{1}{|c|}{ Fungsi } \\
\hline Camera & $\begin{array}{l}\text { Node untuk mengaktifkan kamera dan mengirim data message "Image" ke node } \\
\text { merah, kuning, hijau, dan biru. }\end{array}$ \\
\hline Merah & Node untuk deteksi gerak objek merah. \\
\hline Kuning & Node untuk deteksi gerak objek kuning. \\
\hline Hijau & Node untuk deteksi gerak objek hijau. \\
\hline Biru & Node untuk deteksi gerak objek biru. \\
\hline Hasil_Proses & $\begin{array}{l}\text { Node untuk menerima hasil deteksi objek dari node "Merah", "Kuning",'Hijau", } \\
\text { dan "Biru. }\end{array}$ \\
\hline
\end{tabular}

Berdasarkan informasi tabel 1 dapat dilihat bahwa terdapat enam node yang digunakan untuk memproses data dalam penelitian ini yaitu node "camera", "merah", "kuning", "hijau", "biru”, dan "hasil_proses". Setiap node-node tersebut mempunyai fungsinya masing-masing, seperti node "camera" digunakan khusus untuk mengambil data gambar kemudian mengirimnya ke node "merah", "kuning", "hijau", dan "biru". Selanjutnya pada setiap node tersebut akan memproses data gambar yang diterima sesuai dengan fungsinya masing-masing, seperti node "merah" untuk mendeteksi gerak objek berwarna merah, node "kuning" untuk mendeteksi gerak objek berwarna kuning, node "hijau" untuk mendeteksi gerak objek berwarna hijau, dan node "biru" digunakan untuk mendeteksi gerak 
objek berwarna biru. Selanjutnya pada setiap node "merah", "kuning", "hijau", dan "biru" akan mengaplikasikan metode Binary-Image Comparoson untuk dapat mengirim data message hasil deteksi objek ke node "hasil_proses". Seluruh data message yang diterima oleh node "hasil_proses" akan diolah untuk sistem yang akan dikembangkan pada penelitian ini.

ROS telah di desain untuk dapat menghubungkan proses antar node melalui topic, hal ini akan memudahkan ketika pengembang sistem ingin memproses banyak data secara terpisah dan ingin menghubungkannya antara satu proses dengan proses lainnya. Berikut adalah nama topic yang digunakan untuk menghubungkan antar node pada penelitian ini.

Tabel 2. Nama topic untuk menghubungkan antar node

\begin{tabular}{|c|c|c|c|c|}
\hline Node Publisher & Topic & $\begin{array}{c}\text { Node Subscriber / } \\
\text { Publisher }\end{array}$ & Topic & Node Subscriber \\
\hline \multirow{4}{*}{ camera } & image & merah & hasil_merah & \multirow{3}{*}{ hasil_proses } \\
\cline { 2 - 4 } & image & kuning & hasil_kuning & \\
\cline { 2 - 4 } & image & hijau & hasil_hijau & \\
\cline { 2 - 3 } & image & biru & hasil_biru & \\
\hline
\end{tabular}

Berdasarkan informasi tabel 2 dapat dilihat bahwa terdapat sebuah node publisher "camera" yang mempunyai fungsi untuk mengirim data message gambar (Image) ke node "merah", "kuning", "hijau", dan "biru" melalui topic "image". Selanjutnya node subscriber/publisher "merah", "kuning", "hijau", dan "biru" menerima data message gambar (image) kemudian memprosesnya untuk dapat mendeteksi gerak objek berdasarkan warna objek. Setelah itu hasil deteksi objek akan dikirim ke node subscriber "hasil_proses" menggunakan data message "String" melalui topic "hasil_merah" untuk node "merah", topic "hasil_kuning" untuk node "kuning", topic "hasil_hijau" untuk node "hijau", dan topic "hasil_biru" untuk node "biru". Pada penelitian ini, metode Binary-Image Comparison diaplikasikan didalam node "merah", "kuning", "hijau", dan "biru", metode tersebut digunakan sebagai sistem pengambil keputusan pada saat akan mengirim data message "String" ke node "hasil_proses" sebagai hasil dari deteksi objek.

Pada ROS terdapat tools rqt yang dapat digunakan untuk melihat komunikasi antar node melalui topic. Barikut adalah gambar komunikasi antar node melalui topic yang ditampilkan menggunakan tools rqt.

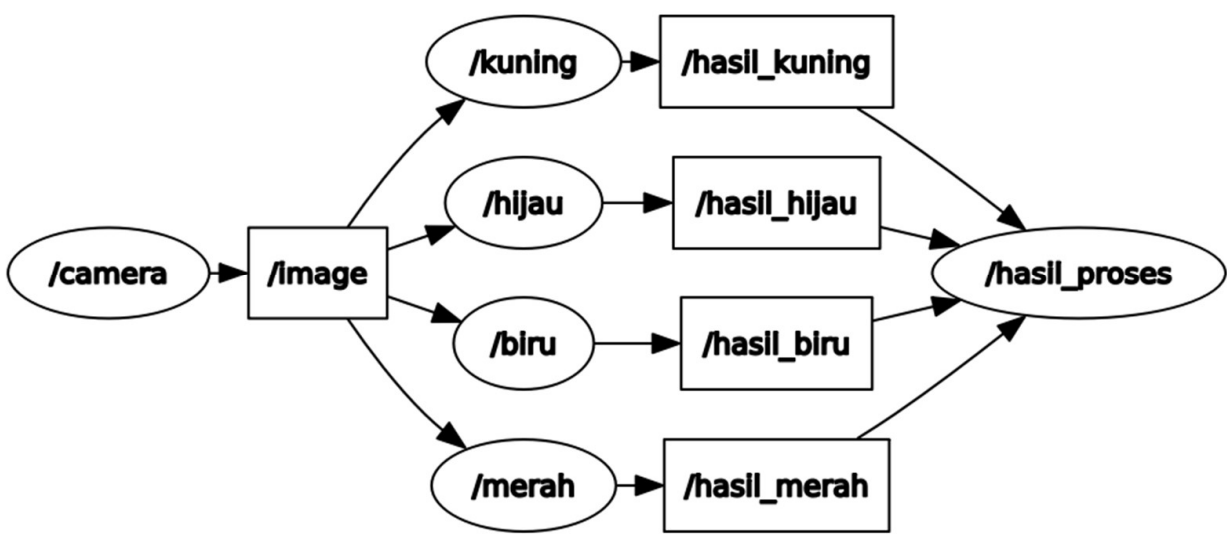

Gambar 2. Proses komunikasi antar node melalui topic

Berdasarkan gambar 2 dapat dilihat node "camera" dapat terhubung ke node "kuning", "hijau", "biru", dan "merah" melalui topic "image". Selanjutnya node "kuning" dapat mengirim data message 
ke node "hasil_proses" melalui topic "hasil_kuning", node "hijau" dapat mengirim data message ke node "hasil_proses" melalui topic "hasil_hijau", node "biru" dapat mengirim data message ke node "hasil_proses" melalui topic "hasil_biru", dan node "merah" dapat mengirim data message ke node "hasil_proses" melalui topic "hasil_merah". Berikut adalah gambar hasil deteksi gerak objek berdasarkan warna yaitu merah, kuning, hijau, dan biru menggunakan metode binary-image comparison.
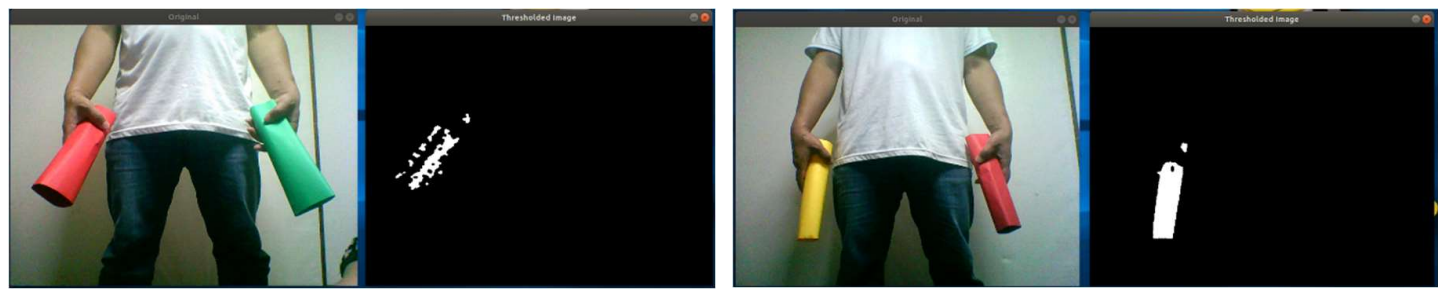

Gambar 3. Deteksi gerak objek warna merah (kiri) dan deteksi gerak objek kuning (kanan)
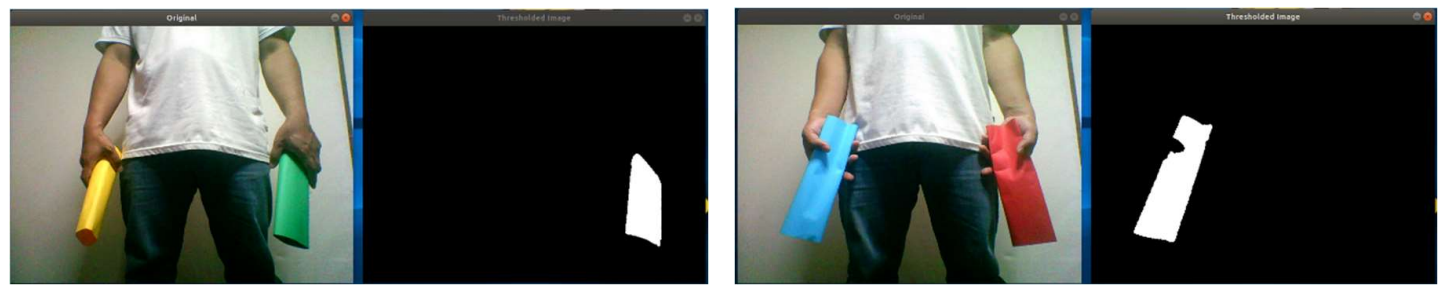

Gambar 4. Deteksi gerak objek warna hijau (kiri) dan deteksi gerak objek biru (kanan)

\section{KESIMPULAN}

Penggunaan metode Binary-Image Comparison dalam mengambil keputusan untuk mengirim data message hasil deteksi gerak objek telah berhasil diaplikasikan pada penelitian ini. Setiap gerak objek yang dideteksi pada penelitian ini telah diproses menggunakan OpenCV dan layanan node ROS2. Objek yang dideteksi pada penelitian ini adalah objek dengan warna merah, kuning, hijau, dan biru. Objek-objek tersebut telah berhasil dideteksi berdasarkan proses yang berjalan didalam node ROS2. Saran untuk pengembangan penelitian kedepannya adalah objek yang dideteksi dapat diproses menggunakan sistem kecerdasan buatan yang saling terhubung antara satu node dengan node lainnya sehingga dapat bekerja lebih efektif dalam mendeteksi gerak objek berdasarkan warna objek

\section{UCAPAN TERIMA KASIH}

Terima kasih kami haturkan kepada KEMENRISTEK DIKTI dan STMIK Handayani Makassar atas dukungannya sehingga Penelitian Dosen Pemula (PDP) ini dapat kami laksanakan dan selesaikan dengan baik.

\section{DAFTAR PUSTAKA}

[1] Basir, B., Wardi., dan Zainuddin, Z. 2017. Sistem Keamanan Rumah Berbasis Kinect. JURNAL IT, Vol.8, No.2, hlm. 84-96.

[2] Riyadi, TA. 2017. Analisis Sistem Pemantauan Video Menggunakan IP Camera Pada Suatu Unit Usaha PTN. Jurnal Teknologi Rekayasa, Vol.22, No.2, hlm.103-112.

[3] Uktoro, AI. 2017. Analisis Citra Drone Untuk Monitoring Kesehatan Tanaman Kelapa Sawit. Jurnal Agroteknose, Vol. VIII, No.II, hlm.8-15. 
[4] Ifan., Musa, MDT., Farhamsa, D. 2015. Alarm Kebakaran Berbasis Citra. Gravitasi, Vol.14, No.1, hlm.90-96.

[5] Pradana, SY., Utaminingrum, F., dan Kurniawan, W. 2018. Deteksi Titik Api Terpusat Menggunakan Kamera Dengan Notifikasi Berbasis Sms Gateway Pada Raspberry Pi. Jurnal Pengembangan Teknologi Informasi dan Ilmu Komputer, Vol.2, No.12, hlm.7183-7191.

[6] Jalil, A. 2018. Sistem Kontrol Mesin Penukaran Uang Kertas Rupiah Berbasis Pengolahan Citra dan Raspberry Pi. ILKOM Jurnal Ilmiah, Vol.10, No.2, hlm.128-135.

[7] Mursalim, MKN. 2018. Pendeteksian dan Pelacakan Objek Bergerak pada UAV berbasis Metode SUED. JNTETI, Vol.7, No.1, hlm.105-111.

[8] Dewi, YF dan Fadilla, N. 2019. Deteksi Objek Berwarna Merah Secara Real Time Dengan Algoritma Color Filtering. Jurnal Media Informatika Budidarma, Vol.3, No.2, hlm.140-143.

[9] Putri, NN. 2016. Aplikasi Pendeteksi Objek Bergerak Pada Image Sequence Dengan Metode Background Substraction. Jurnal Teknologi Rekayasa, Vol.21, No.3, hlm.162-172.

[10] Yuha, RA., Fikri, MDA., Ashari, Pranata, R., dan Harahap, M. 2019. Seminar Nasional APTIKOM (SEMNASTIK), hlm.503-511.

[11] Yunardi, RT., Mardhiyah, AW., Yahya, MH., dan Arisgraha. FCS. 2019. Desain dan Implementasi Visual Object Tracking Menggunakan Pan and Tilt Vision System. ELKHA, Vol.11, No. 2, hal.85-92.

[12] Prabowo, DA., Abdullah, D., dan Manik, A. 2018. Deteksi dan Perhitungan Objek Berdasarkan Warna Menggunakan Color Object Tracking. Jurnal Pseudocode, Vol.5, No.2, hal.85-91.

[13] Muwardi, F dan Fadlil, A. 2017. Sistem Pengenalan Bunga Berbasis Pengolahan Citra dan Pengklasifikasi Jarak. Jurnal Ilmu Teknik Elektro Komputer dan Informatika (JITEKI), Vol.3, No.2, hal.124-131.

[14] Kusumanto, RD dan Tompunu, AN. 2011. Pengolahan Citra Digital Untuk Mendeteksi Obyek Menggunakan Pengolahan Warna Model Normalisasi RGB. Seminar Nasional Teknologi Informasi \& Komunikasi Terapan 2011 (Semantik 2011). ISBN 979-26-0255-0.

[15] Murniyasih, E dan Suryani, L. 2020. Penerapan Metode Learning Vector Quantization Untuk Identifikasi Penyakit Padi Berdasarkan Bentuk Bercak Daun. Jurnal Elektro Luceat, Vol.6, No.1.

[16] Baudrier, E., Millon, G., Nicolier, F., dan Ruan, S. 2006. A fast binary-image comparison method with local-dissimilarity quantification. International Conference on Pattern Recognition (ICPR'06). DOI: 10.1109/ICPR.2006.63.

[17] Paumard, J. 1997. Robust comparison of binary images. ELSEVIER, Pattern Recognition Letters.

[18] Mustafa, AAY. 2019. Fast Size-Invariant Binary Image Matching Through Dissimilarity via Pixel Mapping. International Journal of Engineering Research and Technology, Vol.12, No.8, hal.1293-1306.

[19] Jalil, A. 2018. Robot Operating System (ROS) dan Gazebo Sebagai Media Pembelajaran Robot Interaktif. ILKOM Jurnal Ilmiah, Vol.10, No.3, hal.284-289.

[20] Jalil, A. 2019. Pemanfaatan Middleware Robot Operating System (ROS) Dalam Menjawab Tantangan Revolusi Industri 4.0. ILKOM Jurnal Ilmiah, Vol.11, No.1, hal.45-52.

[21] Maruyama, Y., Kato, S., dan Azumi. T. 2016. Exploring the Performance of ROS2. EMSOFT.

[22] Diluoffo, V., Michalson, WR., dan Sunar, B. 2018. Robot Operating System 2: The need for a holistic security approach to robotic architectures. International Journal of Advanced Robotic Systems. 